\title{
Community Role in Improving Muslim-Friendly Value Chain in COVID-19 Pandemic at Geopark Bayah Dome Tourism Area
}

\author{
Sugeng Santoso ${ }^{1}$, Rian Ubaidillah ${ }^{2}$, Badzlina Balqis ${ }^{3}$, Christiana Fransiska Sembiring ${ }^{4}$ \\ \{sugeng.santoso@mercubuana.ac.id'11255119110083@student.mercubuana.ac.id², \\ rianubay.ops@gmail.com³ $355119110145 @$ student.mercubuana.ac.id ${ }^{4}$, \\ 455119110077@student.mercubuana.ac.id $\left.{ }^{5}\right\}$ \\ Universitas Mercu Buana, Jakarta, Indonesia ${ }^{12345}$
}

\begin{abstract}
The purpose of this research is to know the role of community in improving the value chain of Muslim-friendly tourism in the COVID-19 pandemic at Geopark Bayah Dome Tourism area, Lebak Regency, Banten province. Methodology in this research is using Analytical Hierarchy Process (AHP) obtained by the most important order is the standard new order, then the aspect of the Geopark and later aspects of Muslim-friendly tourism. As for the sectoral aspect obtained six priority aspects, namely the facility with a weight of $16.3 \%$, a tourist attraction with Bobo $15.6 \%$, public awareness with weights $14.6 \%$, geotourism with a weight of $12.6 \%$, health protocols $11.8 \%$, and which is not less critical is management and information with a weight of $10.7 \%$. Qualitative descriptive analysis of primary data collection through focus group discussion (FGD), and secondary data from regional government agencies of Lebak Regency and other sources. The Output is a recommendation of the role of society that can improve the tourism value chain in the tourism area Bayah Dome becomes a geopark and geotourism area, and the majority of residents embrace Muslim can be developed using the concept of Muslim-friendly tourism. In the condition of pandemic COVID-19 that needs to be done from the strategic side of strengthening the rules in the normal new order, then the aspect of the Geopark and then the aspect of Muslimfriendly tourism. As for the sectoral aspect need special attention to facilities, tourist attraction, public awareness, geotourism, health protocols, management and information. Strategies with multiple criteria, your goal is to be one.
\end{abstract}

Keywords: Community Role, Covid-19 Pandemic, Geopark, Muslim Friendly Tourism, Tourism Industry

\section{Introduction}

Pandemic Coronavirus 2019 (COVID-19) is a contagious disease caused by the newly discovered COVID-19 virus. Most people infected with the COVID-19 virus will experience mild to moderate respiratory disease and heal without requiring special treatment. However, for older people and those who have fundamental medical problems such as cardiovascular disease, diabetes, chronic respiratory diseases, and cancer when infected with the COVID-19 virus can cause severe infections and deaths (WHO, 2020). Almost all countries were impacted by the spread of COVID-19, including Indonesia, and it became increasingly apparent that COVID-19 disrupted education, health and economics (Utomo et al., 2020) 
(Saputra \& Saddhono, 2021). Governments around the world are implementing social activity, and distance restriction policies and are encouraged to stay home to stop COVID-19 deployments. Considerations were taken in the framework of the handling of disease outbreak in the world, as quoted from public communication protocols in the framework of COVID-19 (Kemenkes, 2020).

The COVID-19 pandemic conditions provide uncertainty conditions for the tourism industry. As quoted in Lembaga Penyelidikan Ekonomi dan Masyarakat Fakultas Ekonomi dan Bisnis Universitas Indonesia (2018) by definition of UNWTO, tourism is a social, cultural and economic phenomenon defined as the movement of people outside the country or residential area for personal or business/professional purposes, most of which are based on the motive for recreation. Therefore, limited activity affects visitors (consumers) as well as managers. The community is asked to remain at home, giving consequences of declining mobility and fulfilment of the need for tourism to be low (Djausal et al., 2020). As before the pandemic COVID-19. Indonesia has a growth in the tourism industry sector, with the achievement of $(6.8 \%)$ In 2014 . This has surpassed the average national economic growth amounting to $(5.7 \%)$.

Tourism is a variety of tourist activities and supported various facilities and services provided by the community, entrepreneurs, governments, and local governments (UndangUndang Republik Indonesia No 10 Tahun 2009 Tentang Kepariwisataan, 2009). So that the development of tourism in Indonesia become a focus of national development and development to grow Indonesia's economic level. The uniqueness of travel experience is an indicator that is most instrumental in shaping the novelty of travel experience (Munir \& Dwiyanto, 2018). Currently, in the tourism industry the concept of Syariah has become a trend in the global economy, and also a fascination to be seen and enjoyed that deserves to be sold to the tourist market (Zaenuri, 2012). From food and beverage, finance, to lifestyle products. As a new trend of lifestyle, many countries begin to introduce their tourism products with a Muslim-friendly concept. Even countries such as Japan, Australia, Thailand, New Zealand, and so on that is not a country that is not a majority of Muslims also make a tourism product Sharia (Asisten Deputi Penelitian dan Pengembangan Kebijakan Kepariwisataan, 2015).

The increase of Muslim tourists from year to year is the opportunity and challenge for the tourism sector to develop halal tourism. Many countries (both Muslims and non-Muslims) seek to develop halal tourism (Satriana \& Faridah, 2018). The concept of Muslim-friendly tourism can be a new way to develop Indonesian tourism that upholds the culture and Islamic values without eliminating the character and culture of the region (Asisten Deputi Penelitian dan Pengembangan Kebijakan Kepariwisataan, 2015). The development of tourism in Indonesia by using Muslim-friendly tourism concept is also a trend, which guarantees more security and comfort in tourist sites, accommodation, as well as food and beverages. Indonesia whose society is a majority of Islamic religion also has an area that becomes Muslim-friendly tourism, based on Indonesia Muslim Trave Index, (2019), Muslim-friendly tourism destination, namely Lombok, ACEH, Riau, Riau Islands, DKI Jakarta, and West Sumatera. As well as the excellent Muslim-friendly tourism destinations of West Java, DIY, Central Java, and South Sulawesi.

One of the areas that have extraordinary tourism potential and has an ongoing development program, namely Lebak Regency, Banten province. Lebak District in the north is bordered by Serang Regency and Tangerang Regency, to the east by the regency of Bogor and Sukabumi Regency, in the south bordered by the Indian Ocean, and in the West borders Pandeglang Regency. Lebak Regency consists of 28 sub-districts, five subdistricts and 340 
villages. The development of tourism potential in Lebak Regency is a Geopark which is a region of national scale protected areas containing a number of important geological heritage sites, which has the appeal of certain beauty and scarcity, which can be developed as part of the concept of integration of conservation, education and development of the local economy (UNESCO, 2006). The Bayah Dome Geopark tourist area includes Bayah, Cilograng, Cibeber, Panggarangan, Cigemblong, Cihara, Sajira and Bitung Curug. Lebak District is also strong religious, the majority of its inhabitants embrace Islam, it is a positive thing that can be developed with the way the development of Muslim-friendly tourism.

The policy direction in the second year of the RPJMD Lebak Regency 2019-2024 (Government of Lebak Regency, 2019) directed at the development of infrastructure and superstructure that supports the realization of tourist destinations that have high appeal, especially those belonging to the potential area of the Bayah Dome Geopark. The infrastructure is focused on transportation infrastructure, communication and information, and energy resources. At the same time, the superstructure is focused on a variety of main facilities that enable the increasing attraction of objects and tourist destinations for the tourists, such as: Quality of objects/tourist destinations, tourism services facilities, transportation means, the tourism market including the development of souvenir centers, culinary, and others; Various supporting facilities such as Parking facilities, mosque, toilets, and others (government of Lebak Regency, 2019). However, in the business process of Lebak District government which refers to the RPJMD 2019-2024, there is a gap where the business development program has not directly touched the Geopark development program (Andrea \& Santoso, 2020).

These pandemic highlights that tourism should be understood in the context of a greater global economy and politics that will determine the future world in which tourism will operate. We will live in a world of new normal tourism - and that is our world (Zenker \& Kock, 2020). With the gap of COVID-19 pandemic need to plan tourism development impacting the sustainable economy in the tourist area of Geopark Bayah Dome. Sustainable tourism consists of three dimensions, namely the ecological value preservation, the preservation of socio-cultural conditions, and the economically well-maintained sustainability and towards a more advanced development (Qoriah et al., 2019). In addition, facilities should also be noted for the management of tourist sites both physical and nonphysical support that can make visitors enjoy the atmosphere, nostalgic with the past or feel the different environment with their daily life, and harmonize every aspect to create harmony in the atmosphere (Amsal \& Mahardika, 2017). The form of service facilities that can be enjoyed in a destination includes accommodation, transportation in destinations, restaurants, sports facilities and activities, other facilities, and retail outlets (Yoeti, 2008).

The hopes and efforts of local communities to achieve environmental conservation and economic development (through geotourism) are determined by involving local communities in cooperation with other stakeholders (Suyanto et al., 2020). Geotourism is a holistic approach to sustainable tourism that focuses on all the points that can be defined to create an authentic travel experience (Stokes, Cook, \& Drew, 2003). Community Empowerment is a strategy to realize the ability and independence of society (PERMENDAGRI Nomor 7 Tahun 2007, 2007). Therefore, there needs to be the formulation of the role of society that is done in detail with the purpose of improving the Muslim-friendly tourism value chain at the COVID-19 pandemic condition in the Bayah Dome geopark tourism area. This concept is also a new concept that goes along with the new awareness about the need for Muslims to get special service in Tourism (Kalesar, 2010). This community's role is to support the rules that have been compiled by the central and local governments to fight the pandemic COVID-19 
but also open up the potential economic growth. Therefore, it is necessary to have a raft recommendation of safety and health protocols as the tourism industry is gradually reopened (Dube et al., 2020).

The purpose of this research is to know the role of community in improving the value chain of Muslim-friendly tourism in COVID-19 pandemic at Geopark Bayah Dome Tourism area, Lebak Regency, Banten province.

\section{Research Method}

The location of the study is the tourist area of Bayah Dome Geopark Lebak Regency, Banten province. In this research, authors use the Analytical Hierarchy Process (AHP) method which can detail complex or unstructured situations into components arranged in the hierarchical arrangement and provide numerical value with consideration to find which element has the highest priority.

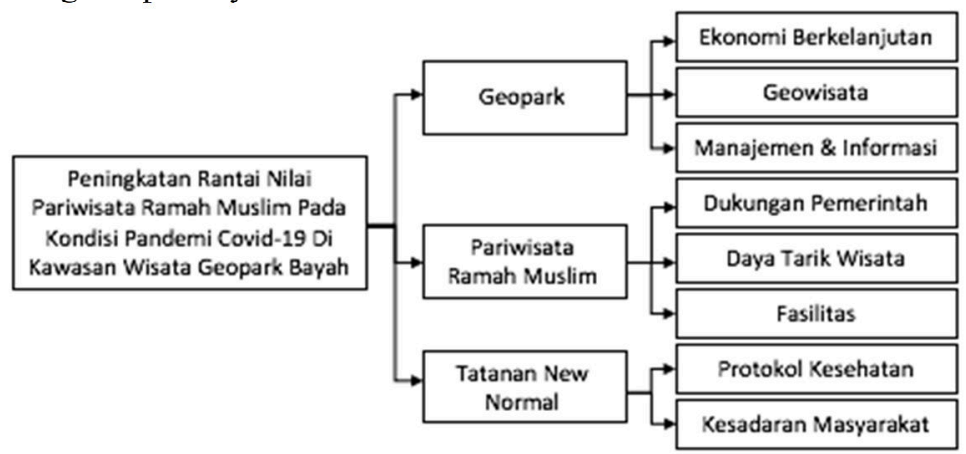

Fig 1. Hierarchy of information

This decision-making Model will outline complex multi-factor or multi-criteria issues into a hierarchy, according to Saaty (2002), a hierarchy defined as a representation of a complex problem in a multi-level structure where the first level is the goal, followed by the level of factors, criteria, sub-criteria, and so on down to the last level of the alternative. Primary data collection techniques using focus group discussion (FGD) conducted online followed by the deputy of industry and investment Kemenparekraf/Baparekraf, District Regent Lebak, head of Bappeda of Lebak District, head of tourism office of Lebak District, head of Cibareno village, tourism manager of Sawarna. Data analysis is done in a descriptive.

This research uses a qualitative method which can mean a method of research based on the philosophy of Post positivism, used to examine on the condition of natural objects (as the opponent of nature is experimentation) where researchers are as a key instrument, sampling data sources performed in purposive and Snowball, a collection technique with triangulation (combined), data analysis is inductive/qualitative, and the results of qualitative research emphasize the meaning of generalization (Sugiyono, 2009). Based on research objectives, this research is included in developmental descriptive research, which is the type of research to find a model or prototype and can be used for all types of fields. In developmental research, data testing was compared to a criterion or predefined preset at the time of drafting the research design (Arikunto, 2019). 


\section{Results and Discussion}

\subsection{Results}

Based on Analytical Hierarchy Process (AHP) that we provide to experts from 3 strategic aspects obtained the results in the most important order is the normal new order, then the aspect of the Geopark and then the aspect of Muslim-friendly tourism. As for the sectoral aspect obtained six priority aspects, namely the facility with a weight of $16.3 \%$, a tourist attraction with Bobo $15.6 \%$, public awareness with weights $14.6 \%$, geotourism with a weight of $12.6 \%$, health protocols $11.8 \%$, and which is not less important is management and information with a weight of $10.7 \%$. This result has also been calculated consistency ratio (CR) to determine the consistency of the matrix. The results obtained for Level 2 or from the strategic aspect is 0.03448 , so the matrix has qualified the consistency is smaller or equal to 0.1 . For level 3 or sectoral aspect of consistency ratio (CR) obtained is 0.03448 , so the matrix has qualified the consistency is smaller or equal to 0.1 .

Based on the focus group discussion (FGD) conducted with the Office of the Ministry of Tourism and Creative Economy of the Republic of Indonesia, the regent of Lebak District and its ranks, and also representatives from the community. From the strategic side of the deputy industry and investment of the Kemenparekraf conveyed the economic and financial Sharia experienced a very rapid development both globally and nationally. Banten province, especially the regency of Lebak chosen because it has extraordinary potential and has a development program that sustains (sustainable). The future tourism trend is outdoor tourism. Lebak has the potential to be outdoor tourism with the development of potential around Bayah Dome to become a geopark and geotourism area, cultural diversity, such as the Baduy tribe, Banten Kidul Kasepuhan, and the majority of people embraced Islam.

Tourism is very influential in the presence of pandemic because it must maintain health in order to curve, but also must maintain the economy. Because it cannot be selected one to go hand-in so that tourism actors and governments should be firm to remind when visitors who do not follow health protocols. Regencies of Lebak conveyed the government of Lebak District focus on building tourism in ecotourism based. The population of Lebak Regency is 99.03\% Muslim, Lebak Regency is an area established by the province of Banten and the central government as a conservation area, $35 \%$ of the area is surrounded by protected forest, private plantation sector, Perhutani, and land owned by the community. The community of Lebak District is encouraged to be a community that DARWIS (tourism conscious) in tourist destinations through tourism development can reach all sectors such as community sector tourism activists, SMEs and communities so that it can interact directly with the tourism sector in Lebak district. Moreover, in adopting a new life in the tourism sector, about the wheels of the economy that must remain running, it is a sign of the conversation. No. 28 years 2020

Head of Bappeda of Lebak District said that the proposal to establish a geological legacy of Bayah Dome through Banten governor to the Geology Agency Ministry of ENERGY and Mineral resources and have been awarded recommendations, and the establishment of the plan of the settlement of Geopark, and the construction of the master plan. Bayah Dome is expected to become an international Geopark and also want to be proposed to the International Geopark Agency. Spread geodiversity Geopark Bayah Dome covers 12 subdistricts with an area of $1,647.33 \mathrm{~km} 2$, and there is 39 geological diversity (Geodiversity) owned in which the international scale there are 12 , national there is 17 , and local there are 10 . 
Some of the potentials that are located along the area of Bayah Dome Geopark include the ancient Delta deposition, beaches, minerals/precious stones, hot springs, waterfalls, caves, ex-gold mines, metamorphic stone granodiorite intrusion, depression Zone, Cikuya tea plantation (some areas in Lebak district which is above 800-1000 above sea level), a potential forest that can be cooperation with National Park and Perhutani. In addition, there is also local wisdom of indigenous Baduy tribe, agricultural Kasepuhan-ampleness of Cisungsang, archaeological site-Kosala site, ex-mining office Antam Cikotok, relics of the occupation-the bridge of Japanese ex-KA, and wood fossil craftsmen. Sharia economic development is expected to maximize local wisdom to capture global opportunities in the form of halal lifestyle trends that prioritize ethical products of goods and services. This view is in accordance with national ideals as an independent, sovereign, fair and prosperous country.

While the head of tourism office of the regency of Lebak conveyed through tourism, Lebak District as a national tourist destination based on local potentials, has a biodiversity of cultural diversity, other ecotourism nature tourism, waterfall, Baduy Sabalik tribe (Banten Kidul unit) bordered by Lebak Regency has 142 nature tourism, consisting of a nature tourism waterfall 68 , nature Tourism 32 , Goa nature Tourism 32, natural hot Springs 4, natural tourism 6 . This amount will increase continuously by starting the development of local-based tourism. In preparing to be able to reopen tourism activities of tourism Department of Lebak District issued DECREE No. 556/KEP. 2116.1/DISPAR/2020 about the new Normal governance guidelines of the tourism business sector in the pandemic conditions COVID 19

Based on a questionnaire filled by tourism area manager of Sawarna, facilities in the tourist area are very important, the facilities needed are public facilities, places of worship, food and beverage services that are Muslim-friendly as well as facilities such as the availability of travel agencies that offer Muslim-friendly travel packages. In addition to the facilities that can improve the tourism value chain in Lebak District is the tourist attraction itself, there is nature tourism like the beach. There is cultural tourism, such as the life activities of Baduy people, and that can enhance the attraction of DARWIS, tourism conscious people can support and develop tourist attraction that is already owned by Lebak Regency. Besides being able to socialize, support and develop Muslim-friendly tourism, the role of society is needed in creating awareness to be able to follow health protocols in the New Normal order, maintain hygiene, maintain distance and also use mass.

\subsection{Discussion}

There is no clear difference between the various terms (halal, Muslim friendly, Islamic etc.) used. Overall, academia uses the term Islamic Tourism while the industry and media use various terms. Among destinations however, there is no clear and consistent use of terminology. A key concern of Islamic tourism is the role of certification in assuring travelers and the lack of standardization of halal certification. (Faiza \& Michelle, 2017). Halal tourism can be summarized as any object or action which is permissible to use or engage in the tourism industry, according to Islamic teachings (M. Battour andIsmail, 2016). Halal tourism is also defined as a type of religious tourism that represents allowable activities under the Islamic teachings in terms of behavior, dress, conduct and diet. (Battour, Hakimian, Ismail, \& Boğan, 2018).

Based on the results of the AHP and the questionnaire, it can be seen that the priority aspect is the facility with a weight of $16.3 \%$. According to the Global Muslim Travel Index as an institution that focuses on developing world Muslim-friendly tourism, it explains that 
there are several things that need to be considered in Muslim-friendly tourism, namely that local governments can fulfill worship services such as prayer facilities, the availability of food and guarantees with a halal label, adequate public facilities. such as toilets with clean water, services and facilities during the month of Ramadan, as well as the absence of alcoholic drink activities and private services that can differentiate between men and women (Subarkah, 2018).

One important market segment of tourism in Islamic destinations, i.e. Halal tourism. During the past decade, Halal tourism has gained much attention from researchers based on the importance of high demand of Muslim tourists who want to comply with the Islamic law, and their high economic contribution worldwide. Halal tourism is a new tourism concept and Jordan is looking forward to getting a share of it. Muslim tourists who want to comply with the Islamic law behave differently based on their religion and their religious belief and, therefore, their Motives to travel are different from other tourists from different religions.(Harahsheh, Haddad, \& Alshorman, 2019).

Based on questionnaires filled out by the manager of Sawarna tourism area, facilities in the tourist area are very important, the facilities needed are public facilities, places of worship, Muslim-friendly food and beverage services as well as facilities such as the availability of travel agencies offering Muslim-friendly travel packages. In addition to facilities that can increase the value chain of tourism in Lebak Regency with the role of the community in socializing, supporting and developing Muslim-friendly tourism.

\section{Conclusion}

The community's role can improve the tourism value chain in the tourist area of Bayah Dome into a geopark and Geotourism neighborhood and community resident population Lebak that Islam can be developed using the concept of Muslim-friendly tourism to create a sense of comfort and safety for tourists. In the condition of the COVID-19 pandemic that needs to be done from a strategic point of view that can assess the rules in the new normal order, then the geopark aspect and the Muslim friendly tourism aspect. Meanwhile, from the aspect of the facility sector, it is necessary to pay special attention to tourist attractions, public awareness, geotourism, health protocols, management, and information. Based on the research "The Role of the Community in Increasing the Value Chain of Muslim Friendly Tourism in the Conditions of the COVID-19 Pandemic in the Bayah Dome Geopark Tourism Area," the authors can:

Encourage community participation to follow health protocols; Maintain cleanliness in the tourist area; Maintain a minimum distance and interaction between fellow communities of 1 meter (physical distancing); Using a mask. Community involvement in community management through tourism awareness groups (POKDARWIS); evaluating visitors by preparing extraordinary impressions that tourists get when visiting the geotourism area, such as souvenirs or memories after visiting Sawarna destinations for them to take home. Imposing a limit on the number of visitors with a maximum limit of 50 percent of capacity; available media for protocol socialization; Checking the body temperature of everyone who wil enter area $(\geq 37.5 \mathrm{oC})$; Carry out cleaning and disinfection in the area of public facilities. Management and information by conducting the latest marketing use multiple languages such as English, Arabic, Chinese and other languages; some experts provide guidance and play an active role in its development. 


\section{References}

[1] Amsal, A. A., \& Mahardika, H. (2017). Pendekatan Experience Economy Pada Pemasaran Festival Pariwisata: Pengaruh Terhadap Kepribadian Festival Yang Dirasakan Pengunjung Dan Reputasi Festival. VII(2), 198-214.

[2] Arikunto, S. (2019). Prosedur penelitian.

[3] Andrea, G., \& Santoso, S. (2020). Improving Economy of the Community Based on Sustainable Tourism and Creative Economy through Business Process Re-Engineering ( BPR ) With Geopark Development in Lebak Regency Banten Province. International Journal of Innovative Science and Research Technology, 5(1), 472-482.

[4] Asisten Deputi Penelitian Dan Pengembangan Kebijakan Kepariwisataan. (2015). Kajian Pengembangan Wisata Syariah Susunan Anggota Kelompok Kerja : In Laporan Akhir Kajian Pengembangan Wisata Syariah.

[5] Battour, M., Hakimian, F., Ismail, M., \& Boğan, E. (2018). The perception of non-Muslim tourists towards halal tourism: Evidence from Turkey and Malaysia. Journal of Islamic Marketing, 9(4), 823-840. https://doi.org/10.1108/JIMA-07-2017-0072

[6] Djausal, G. P., Larasati, A., Ilmu, J., Bisnis, A., Lampung, U., \& Alam, Y. S. (2020). Strategi Pariwisata Ekologis Dalam Tantangan Masa Pandemi Covid-19. Perspektif Bisnis, 3(1), $57-$ 61.

[7] Dube, K., Nhamo, G., \& Chikodzi, D. (2020). COVID-19 cripples global restaurant and hospitality industry. Current Issues in Tourism, 1-4. https://doi.org/10.1080/13683500.2020.1773416

[8] Faiza, K., \& Michelle, C. (2017). Article information: The " Halalification " of tourism Abstract. Journal of Islamic Marketing.

[9] Harahsheh, S., Haddad, R., \& Alshorman, M. (2019). Implications of marketing Jordan as a Halal tourism destination. Journal of Islamic Marketing, 11(1), 97-116. https://doi.org/10.1108/JIMA-02-2018-0036

[10] Kalesar, M. I. 2010. Developing Arab - Islamic Tourism in the Middle East: An Economic Benefit or A Cultural Seclusion. International Politics, 3 (5), 105-136.

[11] Kemenkes RI (2020). Protokol Komunikasi Publik COVID-19. Jakarta

[12] Undang-Undang Republik Indonesia No 10 Tahun 2009 Tentang Kepariwisataan, (2009).

[13] RPJMD Kabupaten Lebak Tahun 2019-2024, Journal of Chemical Information and Modeling (2019). https://doi.org/10.1017/CBO9781107415324.004

[14] PERMENDAGRI Nomor 7 Tahun 2007, (2007).

[15] Lembaga Penyelidikan Ekonomi dan Masyarakat Fakultas Ekonomi dan Bisnis Universitas Indonesia. (2018). Laporan Akhir Kajian Dampak Sektor Pariwisata Terhadap Perekonomian Indonesia. 1, 6-8. https://doi.org/10.16309/j.cnki.issn.1007-1776.2003.03.004

[16] Mastercard-CrescentRating. (2019). Indonesia Muslim Travel Index (GMTI) 2019. In Senin 8 $\begin{array}{llllll}\text { April } & 2019 & \text { Puku } & 19.16 & \text { Wib } & \text { (Issue }\end{array}$ https://lifestyle.okezone.com/read/2019/04/08/406/2040696/kalahkan-aceh-lombok-jadidestinasi- wisata-halal-nomor-satu-di-indonesia

[17] Munir, M. M., \& Dwiyanto, B. M. (2018). Analisis Faktor-Faktor Yang Mempengaruhi Kinerja Rantai Pasokan Pada Bisnis Usaha Mikro, Kecil, Dan Menengah Bidang Kuliner Di Kabupaten Kendal. Jurnal Studi Manajemen Organisasi, $15(1), \quad 10$. https://doi.org/10.14710/jsmo.v15i1.21245

[18] Qoriah, D., Ungkari, M. D., \& Muharam, H. (2019). Pengembangan Pariwisata Berkelanjutan Wisata Domba Adu di Desa Rancabango Tarogong Kaler Garut. Journal of Knowledge Management. https://doi.org/10.1016/j.tmp.2019.06.002

[19] Saaty, T. L. (2002). Decision making with the Analytic Hierarchy Process. Scientia Iranica, 9(3), 215-229. https://doi.org/10.1504/ijssci.2008.017590

[20] Satriana, E. D., \& Faridah, H. D. (2018). Halal Tourism: Development, Chance and Challenge. Journal of Halal Product and Research, 1(2), 32. https://doi.org/10.20473/jhpr.vol.1issue. $2.32-43$

[21] Stokes, A.M., Cook, S.D., \& Drew, D. (2003). Geotourism: New Trends on the Way. National 
Association of Travel Industry and Geographical Travelers.

[22] Subarkah, Alwafi Ridho. 2018. Potensi dan Prospek Wisata Halal Dalam Meningkatkan Ekonomi Daerah (Studi Kasus : Nusa Tenggara Barat). Jurnal Sospol Vol.4 No.2 .

[23] Sugiyono: Educational Research Methodology, Quantitative Approaches, Qualitative, and R \& D, Alfabeta, Bandung: 2009

[24] Suyanto, A., Haryono, E., \& Baiquni, M. (2020). The community-based conservation management in gunung sewu unesco global geopark case study of Nglanggeran Geoheritage. IOP Conference Series: Earth and Environmental Science, 451(1), 1-9. https://doi.org/10.1088/1755-1315/451/1/012049

[25] UNESCO. (2006). Guidelines and Criteria for National Geoparks seeking UNESCO's assistance to join the Global Geoparks Network (GGN).

[26] Who.int. (2020). Pertanyaan dan jawaban terkait Coronavirus. Diakses pada 18 Mei 2020, dari https://www.who.int/indonesia/news/novel-coronavirus/qa-for-public

[27] Yoeti, Oka A, 2008. Tourism Planning and Development. Pradnya Paramita: Jakarta.

[28] Zaenuri, Muchamad. 2012. Strategic Planning Regional Tourism: Concepts and Application. Jogjakarta: e-Gov Publishing.

[29] Zenker, S., \& Kock, F. (2020). The coronavirus pandemic - A critical discussion of a tourism research agenda. $\quad$ Tourism https://doi.org/10.1016/j.tourman.2020.104164

[30] Saputra, A. D., \& Saddhono, K. (2021). Pembelajaran Bahasa Indonesia Menggunakan Microsoft Office Team 365 untuk SMA di Masa Pandemi. LINGUA : Jurnal Bahasa, Sastra, Dan Pengajarannya, 18(1), 16-21. https://doi.org/https://doi.org/10.30957/lingua.v18i1.669

[31] Utomo, M. N. Y., Sudaryanto, M., \& Saddhono, K. (2020). Tools and Strategy for Distance Learning to Respond COVID-19 Pandemic in Indonesia. Ingénierie Des Systèmes d'Information, 25(3), 383-390. https://doi.org/https://doi.org/10.18280/isi.250314 